\title{
Charles Darwin as a Student in Edinburgh, $1825-27^{*}$
}

\author{
By Prof. J. H. Ashworth, F.R.S.
}

\begin{abstract}
CHARLES DARWIN in his autobiography, written in 1876, gives in half a dozen pages ("Life and Letters", I, pp. 36-42) an account of his two academic sessions as a medical student in Edinburgh. This account includes brief references to his naturalist friends and acquaintances, a statement that he collected specimens in the tidal pools on the shore of the Firth of Forth and by going out with the "trawlers", and that he made new observations on the "so-called ova of Flustra", which "were in fact larvæ", and on the egg-cases of Pontobdella muricata.
\end{abstract}

It is now possible to form a more adequate conception of his early progress as a naturalist with the help of the minute book of the Plinian Society of the University of Edinburgh and of a notebook begun by Darwin in Edinburgh in March 1827, the latter of which I have been permitted to see by the kindness of Prof. C. G. Darwin and Mr. Bernard Darwin.

Charles Robert Darwin came to Edinburgh at the age of sixteen years and eight months, and with his elder brother Erasmus, who had been a medical student at the University in the previous year, signed the matriculation book, "Charles Darwin-Shropshire", on October 22, 1825. His class cards for the academic year 1825-26 were presented to the University of Edinburgh by the late Sir Francis Darwin in 1909, together with the wrapper inscribed by Darwin, in which they were found among his papers. The cards are : For the University Library, materia medica, chemistry, anatomy, clinical lectures, principles and practice of surgery and a 'perpetual ticket' for the Royal Infirmary.

In his autobiography, Darwin writes that the lectures "were intolerably dull, with the exception of those on chemistry by Hope. . . . Dr. Duncan's lectures on Materia Medica at 8 o'clock on a winter's morning are something fearful to remember. Dr. - made his lectures on human anatomy as dull as he was himself". The "Dr." referred to was Alexander Monro tertius, who did not sustain the great reputation made by his grandfather and his father, who had preceded him in the chair of anatomy. Darwin attended the clinical lectures and he records that he also "attended regularly the clinical wards in the hospital". He enrolled in the class of 'Principles

* From an address to the Royal Society of Edinburgh on October 28 , part of which formed the subject of a paper to Section $\mathrm{D}$ (Zoology) of the British Association at Norwich. and Practice of Surgery', but all that is known about his attendance in this subject is his own note that on two occasions he was present at "very bad operations"- - these were before the days of chloroform-and that he "rushed away before they were completed".

In his second year at the University, Darwin enrolled in the classes of midwifery, practice of physic and natural history.

Robert Jameson, then fifty-two years of age, was, and had been for twenty-two years, professor of natural history, which then included zoology and geology. He devoted himself chiefly to mineralogy, but his published work shows his interest also in marine zoology and in birds, and as editor of the Edinburgh Philosophical Journal and of the New Philosophical Journal, he maintained a wide outlook on science in general. $\mathrm{He}$ formed an extensive and important natural history museum in the University of Edinburgh, which was notable for the excellent state of preservation of its specimens and their scientific arrangement and for its large collection of birds. The entire museum collection, said to have been, in Great Britain, "second only to that of the British Museum", was handed over a year after Prof. Jameson's death to the new Government Museum of Science and Art, now the Royal Scottish Museum.

Darwin found Prof. Jameson's lectures "incredibly dull" ; "the sole effect they produced on me was the determination never as long as I lived to read a book on Geology, or in any way to study the science". Fortunately, he did not adhere to this decision; within ten years he had made the observations for his three geological memoirs, one of which, on coral reefs, has become a classic.

The detailed syllabus of Prof. Jameson's lectures, as drawn up by him in 1826, shows the range of his teaching, which included not only zoology and geology but also instruction in meteorology and hydrography and some reference to botany in its relation to "the animal and mineral kingdoms". The course of zoology began with a consideration of the natural history of man, was followed by an account of the chief classes of vertebrates and invertebrates, and concluded with lectures on the philosophy of zoology in which the first subject was "Origin of the Species of Animals".

This would be the course as given in Darwin's second academic year, and the lectures, which 
began on November 8,1826 , were on five days a week and were stated to extend over five months ; hence there would be about one hundred lectures, in addition to which there were 'conversations' with the professor in the Museum, and excursions. While Prof. Jameson's teaching of some parts of geology was unacceptable owing to his adherence to extreme and discredited Wernerian views, the recorded judgments of Robert (later Sir Robert) Christison and of Edward Forbes on his teaching in general and on his enthusiasm for his subject and for the Museum under his charge show that they did not share Darwin's opinion of Prof. Jameson's course.

Although Darwin apparently did not receive from Prof. Jameson's lectures much instruction in zoology, he was able to acquire in other ways while in Edinburgh a considerable acquaintance with this subject.

Soon after coming to Edinburgh, Darwin became aware that his father would leave him "property enough to subsist on with some comfort" and this was, as he states, "sufficient to check any strenuous effort to learn medicine". Much of the time available after his attendance at classes would probably be devoted to his pursuit of natural history, especially during his second year when his brother was no longer with him in Edinburgh. His classes were in the same building as the Natural History Museum, and therefore any spare time could be immediately put to good use in the Museum, where he was likely to find at work two experienced naturalists, Dr. Robert Grant and William Macgillivray, whom he came to know well. Further, his membership of the Plinian Natural History Society brought him into association with other enthusiastic naturalists in Edinburgh at that time.

The Plinian Society was founded in 1823 , and the two minute books from February 1826 to the end of the Society's existence in 1841 are preserved in the University Library. The Society, which met every Tuesday evening in the College or University of Edinburgh, had about one hundred and fifty members, but the number recorded as being present at the meetings does not usually exceed twenty. five. The secretary in February 1826 was Dr. Robert Grant, and the record includes the names of those present and of those who took part in the discussions.

Darwin was elected a member of the Society on November 28, 1826, and at the meeting a week later, at which the election of officers and council took place, he was chosen as one of the five members of the council, from which it may be concluded that he was very favourably known for his interest in natural history. There were five presidents-Messrs. Ainsworth, Coldstream, Kay,
Browne and Fife-three of whom, Browne, Coldstream and Fife, had proposed Darwin for membership of the Society. He states in his autobiography that he found the meetings of the Society stimulating and that he "used regularly to attend"; the record shows that he was present at all but one of the nineteen meetings held from the date of his election to April 3, 1827.

The minute book is of interest as showing the subjects discussed in the students' natural history society in Edinburgh one hundred years ago, and it indicates the wide range of the communications presented during the period of Darwin's membership. Darwin is noted as having participated in the discussions on four of the evenings ; it would have been particularly interesting to know what he said on the principles of natural classification and especially on specific characters when he spoke in the discussion on that subject.

On March 27, 1827, not "at the beginning of the year 1826" as stated in the autobiography, "Mr. Darwin communicated to the Society two discoveries which he had made:

(1) "That the ova of the Flustra* possesses organs of motion".

(2) "That the small black globular body hitherto mistaken for the young of Fucus lorius [loreus] is in reality the ovum [or, as he wrote in the autobiography, the egg-case] of the Pontobdella $\uparrow$ muricata".

At the request of the Society, Darwin promised to draw up "an account of the facts and to lay it, together with specimens, before the Society next evening". The minute of the next meeting records that he presented to the Society "a specimen of the Pontobdella muricata with its ova and young ones", but does not mention any account, and if the manuscript was placed before the Society it has not been kept.

In his note-book, Darwin gives under the date April 20 a short account of the yellow embryos and ciliated larvæ of Flustra carbasea, records that two other species produced motile "ova" and adds a description of the egg-cases of Pontobdella and of the young leech when ready to escape. These observations, which occupy four and a half pages of the note-book, were not published by Darwin.

Three days previous to Darwin's paper at the Plinian Society, that is, on March 24, 1827, Dr. Grant read to the Wernerian Natural History Society of Edinburgh, as the minute under that date records, "A Memoir regarding the Anatomy and Mode of Generation of Flustræ, illustrated by preparations and drawings", and "a notice on the Mode of Generation of the Pontobdella muricata of Lamarck".

* Flustra, the 'sea-mat', a genus of Polyzoa, obtained by dredging or found thrown up on the shore-the brown sea-weed now known as Himanthalia lorea.

+ Pontobdella, a leech frequently found on the skate and hence often called by the fishermen the skate-leech. 
Grant's paper contains a more detailed account than Darwin's of the ova of Flustra and of the ciliated embryos and larvæ which Grant reared in watch-glasses into young colonies.

Grant prepared a description of the cocoons of Pontobdella, published in the Edinburgh Journal of Science of July 1827, in which he stated that "the merit of having first ascertained them to belong to that animal is due to my zealous young friend Mr. Charles Darwin of Shrewsbury, who kindly presented me with specimens of the ova exhibiting the animal in different stages of maturity".

Another significant factor in Darwin's studies in natural history in Edinburgh was his friendship with some of the Newhaven fishermen, whom he sometimes accompanied when they dredged for oysters "and thus got many specimens". His notebook records Pennatula mirabilis (now Virgularia mirabilis) and Pennatula phosphorea from the Firth of Forth, which were no doubt obtained in that way; the cocoons of Pontobdella which he found on oyster and other shells were probably collected on some of these expeditions, and he procured his specimens of Flustra carbasea "from the dredge boats at Newhaven".

Darwin's note-book, which is inscribed on the fly-leaf "Charles Robert Darwin, March 1827", provides interesting evidence of his observations on animals collected in the Firth of Forth. He found a lumpsucker stranded on the rocks at Leith and "dissected it with Dr. Grant"; a fairly complete examination was made of its internal organs including the heart and its valves. $\mathrm{He}$ records and sketches the "ova" (egg-masses) of several molluscs, adds sketches of the ciliated larvæ of three of them, and gives brief descriptions of the two sea-pens, Virgularia mirabilis and Pennatula phosphorea, which he had procured no doubt with the help of the Newhaven fishermen. The last zoological entry in the note-book is that he "observed with Mr. Coldstream" a starfish, which he identified as Asterias rubens, but which was almost certainly a specimen of the closely similar starfish first differentiated from rubens as a new genus and species by Michael Sars in 1846 and now known as Leptasterias mülleri. Darwin saw his starfish in the act of discharging its eggs. In this species the eggs are incubated in the space enclosed by the arched disc and the inwardly bent bases of the arms.

With Darwin's Edinburgh notes were two lists of animals, one of "the Vermes found in the Frith of Forth and other parts of Scotland" abstracted from a paper by Prof. Jameson (1811), and the other of "Fishes found in the Frith of Forth" from a paper by Patrick Neill (1811). Each list was written on two double sheets, about 6 in. $\times 3 \frac{1}{2}$ in., and the two sheets were fastened together by a strip of gummed paper. These lists could be carried in a pocket-book, and would be convenient for reference in his collecting expeditions.

Darwin left Edinburgh late in April 1827, when little more than eighteen years of age, and early in the following year went to Cambridge.

Reference was made to Darwin's friends in Edinburgh, of whom the most important was undoubtedly Dr. Robert Edmund Grant, then about thirty-three years old. He had graduated M.D. Edinburgh in 1814 and had studied natural history and medicine in 1815-20 in Paris and other Continental universities. He returned to Edinburgh in 1820 and explored the coasts of Scotland and Ireland and made studies, including dissections, of many animals which he collected. Grant was the author of a series of papers on sponges in 1825 and 1826, and many of the observations therein recorded were made on the shores of the Firth of Forth. In addition, he published or wrote, in the years 1825-27, more than a dozen other papers on Cœelenterata, Mollusca Polyzoa, Crustacea, on the structure of the eye of the sword-fish, and on the anatomy of the paca of Brazil ; he was at that time a most energetic collector and investigator, especially of marine invertebrates. Darwin states that he often accompanied Grant to collect animals in the tidal pools, and he records in his note-book that he dissected with Grant the lumpsucker he had found at Leith. It was a great advantage to Darwin to have this experienced zoologist as his friend.

In his autobiography Darwin relates that one day when he was walking with Grant the latter "burst forth in high admiration of Lamarck and his views on evolution"; Darwin adds that he listened in silent astonishment, and so far as he could judge without any effect on his mind. That exposition on Lamarck acquires fuller significance when it is remembered that Grant studied in Paris during the period 1815-20, and that he would devote much of his time to work in the Museum of Natural History, where he would very probably come into association with Lamarck only a few years after the latter had published his "Philosophie Zoologique" (1809) and while he was preparing his great work on the natural history of invertebrates (1815-22).

In the summer of 1827 Grant left Edinburgh to become the first professor of zoology in University College, London.

William Macgillivray, thirteen years Darwin's senior, was, during the time Darwin was a student in Edinburgh, assistant and secretary to Prof. Jameson and acted as assistant-keeper of the University Museum of Natural History. He was known for his papers on molluses and on birds, and 
was afterwards (1841) appointed professor of natural history in Aberdeen. With him Darwin "had much interesting natural-history talk", and while birds are not specifically mentioned, it is scarcely possible that Darwin could be in frequent association with Macgillivray-whom the late Prof. Alfred Newton regarded, after Willughby, as "the greatest and most original ornithological genius save one (who did not live long enough to make his powers widely known) that this island has produced"-without utilising such an opportunity of acquiring some of his special knowledge of the classification and structure of birds. Darwin records that in Edinburgh he had lessons on preparing birds from a Negro who had travelled with Waterton, and there is extant evidence of his interest in birds at this time in two 'keys' in manuscript found among his Edinburgh notes. One is a key to the genera of British birds and the other, to about one hundred genera of birds, was "copied from Brisson's Ornithologie, 4th Edit. ... 1826", hence it was written during his second academic session.

Darwin "became well acquainted with several young men fond of natural science". He mentions Ainsworth, Coldstream and Hardie (this should be
Arding, a member of the council of the Plinian Society), but he might have added the other presidents of the Plinian Society-Kay, Browne (father of Sir James Crichton-Browne) and Fife, with whom also he would be frequently associated during his last five months in Edinburgh. These men were all senior to Darwin by two to four years; Browne was already L.R.C.S. and the others qualified in medicine in 1827.

Darwin attended, with Grant, meetings of the Wernerian Natural History Society and heard, among others, Audubon, who spoke at the meetings in December 1826 and January and February 1827, and he was present at one meeting of the Royal Society of Edinburgh, where he saw Walter Scott in the chair as president.

I suggest that if, with the information now available, Darwin's experiences in Edinburgh are reviewed, there are good grounds for the conclusion that, while he gained comparatively little from the formal lectures, he had excellent opportunities, of which he appears to have availed himself fully, of developing his early taste for natural history and collecting, and that in Edinburgh he laid the foundation of his knowledge of the science of natural history.

\section{Utilisation of Pine Forests}

\section{Cellulose Pulp}

\section{A} STUDY of the methods of utilising the vast areas of pine forests which occur in various parts of the world is a matter of considerable importance from the scientific and economic points of view, and both aspects have recently received considerable attention in Australia and in the United States. In each case the manufacture of cellulose pulp for the paper and allied industries has been the main objective; but the problem has been approached from somewhat different aspects in the two countries. Thus, the American workers have erected a large-scale experimental plant, and have carried out numerous pulping trials, whilst in Australia a more fundamental study of the chemistry and structure of the woods has first been made, with small-scale pulping trials to provide additional information. The two studies are therefore, in a sense, complementary ; and it is interesting to consider them together.

It is well known that the objection to the use of the southern type of pine for pulping has always been the high resin content, which is a source of considerable trouble to the paper-maker.
It is true that the soda and sulphate (kraft) processes of digestion remove most of this, but such methods are not always desirable for economic reasons. The mechanical and acid (sulphite) processes, which are generally preferred, provide no solution of the resin problem; ; it seems, in fact, that the latter induces polymerisation of the resins, which are thereby converted into an objectionable substance resembling pitch.

The key to the problem appears to be the differentiation of the sapwood and the heartwood, and it has been found from investigations on thinnings, which contain very little resinous matter, that the elimination of heartwood also eliminates the resin trouble. As an example, in the case of the longleaf pine, the average figures given for the resin in the sapwood and heartwood are 2 and 7-10 per cent, respectively. With this is also involved the question of the diameter of the tree, because in the past there probably has not been a full appreciation of the great diameter to which a tree can grow before the sapwood begins its transformation into heartwood ; this is in spite 